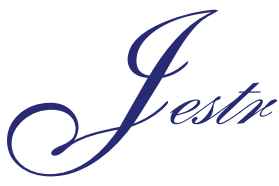

Journal of Engineering Science and Technology Review 2 (1) (2009) 145-150

JOURNAL OF

Engineering Science and

Technology Review

Research Article

www.jestr.org

\title{
Energy Absorption Capacity of Composite Beams
}

\author{
Arivalagan ${ }^{* 1}$ and Kandasamy ${ }^{2}$

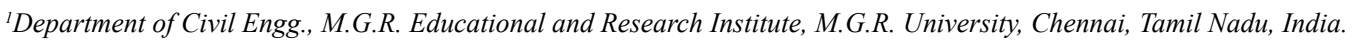 \\ ${ }^{2}$ Dean, Anna University-Trichirappali, Ariyallur Campus, Ariyallur,Tamil Nadu, India.
}

Received 1 June 2009; Revised 15 October 2009; Accepted 3 November 2009

\begin{abstract}
Local buckling may occur in the compression flange of rectangular hollow-section beams under cyclic repeated loading arising from earthquakes. Once a local mechanism forms, residual strength rapidly reduces within a few cycles. This is true even for compact sections under static bending. This paper aims to study the experimental behaviour and ultimate moment capacity of unfilled and concrete-filled rectangular hollow sections subjected to cyclic reversible loading. Two types of filler material were used - normal mix concrete and fly ash concrete. The effect of filler materials, section slenderness, loaddeflection response, moment-strain behaviour, first cycle peak load, ductility, stiffness degradation and energy absorption of concrete -filled RHS beams are studied.
\end{abstract}

Keywords: Cyclic loading, normal mix concrete, fly ash concrete, energy absorption capacity

\section{Introduction}

Concrete-filled steel tubes -CFSTs are used in many structural applications including columns, supporting platforms of offshore structures, roofs of storage tanks, bridge piers, piles, and columns in seismic zones (Kilpatrick and Rangan 1995). Concrete-filled steel box columns offer excellent structural performance, such as high strength, high ductility and large energy absorption capacity and have been widely used as primary axial load carrying members in high-rise buildings, bridges and offshore structures $(\mathrm{Lu}$ and Kennedy, 1994). Application of the CFST concept can lead to overall savings of steel in comparison with conventional structural steel systems. In CFST composite construction steel tubes are also used as permanent formwork and to provide well-distributed reinforcement (Assi, 2003; Furlong 1967). Test results have shown that the concrete core delays local buckling and forces the steel tube to buckle outwards rather than inwards, resulting in a higher flexural strength therefore, tubes with thinner walls could reach yield strength before local buckling occurs (Zhao, 1999; Lu and Kennedy 1994). Zhao et al $(1999,2002)$ and Elchalakani et al (2003) conducted experiments on concrete filled steel tubes from this study following inferences are obtained due to filling of steel hollow tube with concrete an increase in flexural strength are obtained. Furlong (1967) reported that using expansive cement enhances the bond and provides chemically prestressed elements and the steel tube is axially loaded the confinement effect is delayed until the expansion of concrete overcomes that of the tube. The composite action and bond in CFST were also studied by Hunaiti (1997) from this study

* E-mail address: arivu357@yahoo.co.in ISSN: 1791-2377 (C) 2009 Kavala Institute of Technology. All rights reserved. following interesting findings are observed under axial compression, the steel tube confines the concrete which improves both the axial load resistance and ductility of the CFST members. Different researchers concluded that confinement effectiveness is reduced by using rectangular or square tubes, by using high strength concrete by increasing the slenderness of columns and pure flexural members (Furlong 1967; Lu and Kennedy 1994; Kilpatrick and Rangan 1995). The test conducted by Angeline Prabhavathy et al (2006) in filled frames, showed that concrete in-filled beams give additional stiffness, which delays the failure of the columns. Design specifications CIDECT are very conservative due to the lack of consideration of the confinement effect in CFST. The main objective of this cyclic test program is to obtain experimental data and to study the hysteretic behaviour of CFST beams with different infill materials.

1. The special characteristics of the current testing program include

2. Thin walled section (thickness $=3.2 \mathrm{~mm}$ )

3. The depth -to-thickness ratio $(\mathrm{d} / \mathrm{t}$ ratio $=29.25)$

4. Yield strength of the steel section (yield stress up to $355 \mathrm{Mpa}$ )

5. Two different filler material (normal mix concrete and fly ash concrete) and

6. Cyclic reversible loading system

7. The experimental results of Hollow, Concrete-filled RHS beams and the CIDECT standard are compared.

\section{Experimental Program}

\subsection{Material properties}

Totally nine specimens consisting of three Rectangular Hollow 
specimens (RHS) and six Concrete Filled Steel Tubes (CFST) consisting of each three normal mix concrete specimens and three fly ash concrete specimens were used.The sizes of RHS section were selected as 100x 50x3.2 mm. The Grade of Steel is Yst310 in accordance with IS 4923:1997 "INDIAN STANDARD HOLLOW STEEL SECTIONS FOR STRUCTURAL USE - SPECIFICATIONS". The basic strength of RHS beams are 355Mpa(nominal yield stress, fy). The calculated (d/t) ratio is 29.25. The beams are designed as simply supported as is common practice for designing structural elements as shown in Fig.1. The length of the specimen was $1.2 \mathrm{~m}$. In the current research, RHS tubes were supplied by TATA Steel Industries (p) Ltd., India. The nominal dimensions for the RHS sections used in this research are shown in Table 1.

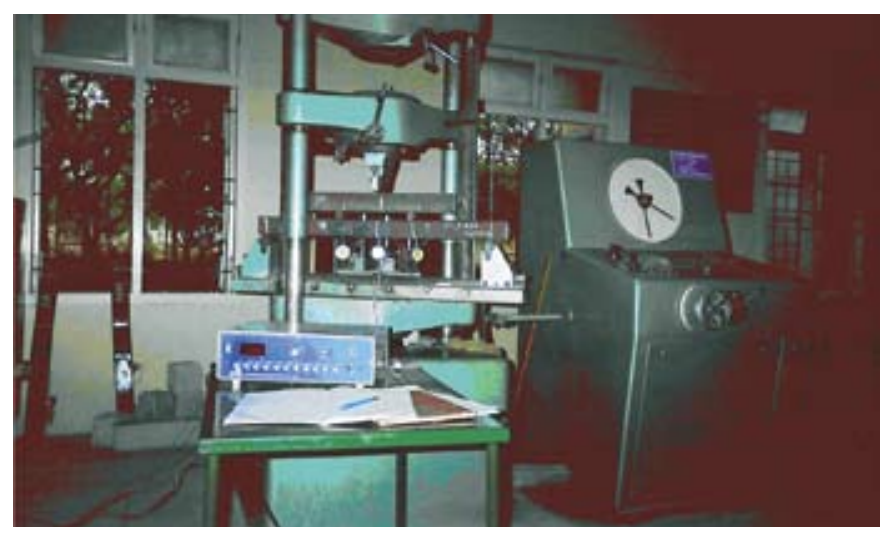

1. Testing arrangement of specimen

Table 1. Details of test specimens

\begin{tabular}{|c|c|c|c|c|}
\hline $\begin{array}{c}\text { Specimen } \\
\text { Label }\end{array}$ & $\begin{array}{c}\text { Dimensions } \\
\text { of the Speci- } \\
\text { men (D. B. t) } \\
\text { mm }\end{array}$ & $\begin{array}{c}\text { Area of } \\
\text { steel }\left(\mathbf{A}_{\mathbf{s}}\right) \\
\text { mm }^{2}\end{array}$ & $\begin{array}{l}\text { Area of } \\
\text { in-filled } \\
\text { Concrete } \\
\left(\mathbf{A}_{\mathbf{c}}\right) \mathbf{m m}^{2}\end{array}$ & $\begin{array}{c}\text { Types } \\
\text { of Filled } \\
\text { Concrete }\end{array}$ \\
\hline NMC & $100 \times 50 \times 3.2$ & 919.04 & 4080.9 & $\begin{array}{l}\text { Normal Mix } \\
\text { Concrete }\end{array}$ \\
\hline FAC & $100 \times 50 \times 3.2$ & 919.04 & 4080.9 & $\begin{array}{l}\text { Fly Ash } \\
\text { Concrete }\end{array}$ \\
\hline RHS & $100 \times 50 \times 3.2$ & 919.04 & - & $\begin{array}{c}\text { Rectangular } \\
\text { Hollow } \\
\text { Section }\end{array}$ \\
\hline
\end{tabular}

To obtain the basic properties of steel sections, three tensile coupons were extracted from the flat surface of the tube. The tensile coupon tests were conducted according to the Indian standard specification "IS: 1608-1972 "METHOD FOR TENSILE TESTING OF STEEL PRODUCTS". Geometrical properties of the steel section are given in Table 2 .

Table 2. Average material properties of the Steel specimen

\begin{tabular}{cccc}
\hline $\begin{array}{c}\text { Yield Stress (fy) } \\
\text { Mpa }\end{array}$ & $\begin{array}{c}\text { Ultimate stress } \\
\text { (fu) } \mathbf{M P a}\end{array}$ & $\mathbf{d} / \mathbf{t}$ & $\mathbf{f u} / \mathbf{f y}$ \\
\hline 355 & 500 & 29.25 & 1.41 \\
\hline
\end{tabular}

The concrete used had a water-cement ratio of $50 \%$ (by weight). The filler material consisted of normal mix concrete and fly ash concrete with different compression strengths and densities.
The mechanical properties of the concrete were then determined from the average compression test results on three cubes $(150 \mathrm{~mm}$ $\mathrm{x} 150 \mathrm{~mm} \times 150 \mathrm{~mm}$ ) in each series. Concrete cubes were cured for 28 days to determine the compression strength. The concrete cube tests were carried out on the same day as the beam tests. The measured properties for the filler material are listed in Tables 3 .

Table 3. Average Concrete cube strengths

\begin{tabular}{cccc}
\hline $\begin{array}{c}\text { Type of Con- } \\
\text { crete }\end{array}$ & $\begin{array}{c}\text { 28 days cube compres- } \\
\text { sive strength }\left(\mathbf{N} / \mathbf{m m}^{2}\right)\end{array}$ & $\begin{array}{c}\text { Cylinder } \\
\text { strength } \\
\left(\mathbf{N} / \mathbf{m m}^{2}\right)\end{array}$ & $\begin{array}{c}\text { Density of } \\
\text { Concrete } \\
\left(\mathbf{K g} / \mathbf{m}^{3}\right)\end{array}$ \\
\hline $\begin{array}{c}\text { Normal mix } \\
\text { concrete }\end{array}$ & 37.0 & 29.6 & 2400 \\
\begin{tabular}{c} 
Fly ash concrete \\
\hline
\end{tabular} & 35.0 & 28.0 & 2100 \\
\hline
\end{tabular}

\subsection{Test procedures}

Three RHS and six concrete filled specimens were tested. They are summarized in Table 1. Where the specimen label, dimension of the specimen and types of filled concrete are given in which designation starts with RHS, NMC \& FAC (Rectangular Hollow section, Normal Mix Concrete and Fly Ash Concrete). The $400 \mathrm{kN}$ capacity UTM (universal testing machine) was used to perform the test. Each specimen was subjected to reversible cyclic bending. The test procedure of cyclic reversible load is described below.

The test specimen was arranged in a manner of simply supported condition. The load was applied by two-point method at onethird distance of the span of the specimen. The load was applied gradually through a jack at an increment of $5 \mathrm{kN}$. In the first cycle load was applied to a maximum of $40 \mathrm{kN}$ then the specimen was unloaded with a decrement load of $5 \mathrm{kN}$. The load was brought to zero. Afterwards the specimen was turned over and arrange in the position of simply supported condition and the cycle test was performed as described above. Thus one complete cycle of loading and unloading was performed .In second, third, fourth and fifth cycles the load reaches in each cycle is $50 \mathrm{kN}, 60 \mathrm{kN}, 70 \mathrm{kN}$ and $80 \mathrm{kN}$ respectively. Deflectometers were placed under the loading point and the centre (midspan) of the specimen to measure the deflections. Strain gauges were also used to measure the strain values these are fixed at centre (midspan) of the beam specimen and in top and bottom faces of the beam specimen. From the deflection and strain values, Load- Deflection and Moment - Strain behavior was studied. Figure 2 shows the method to apply the load to cyclic test.

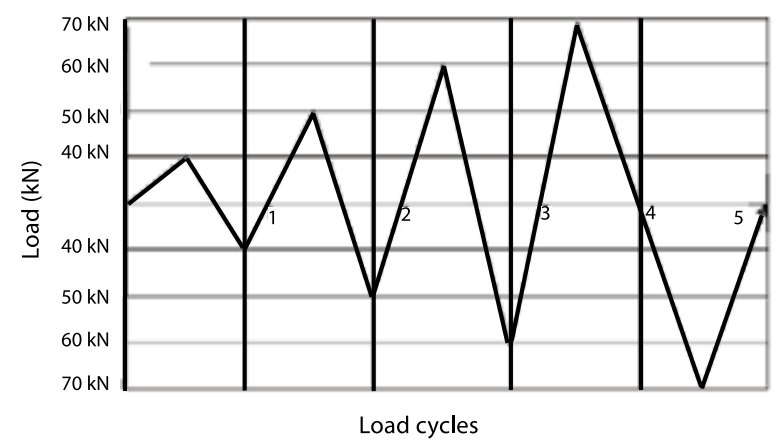

Fig. 2. Cyclic loading diagram 


\section{Results and Discussion}

\subsection{Moment Carrying Capacity}

The moment carrying capacity of the hollow and concrete-filled RHS beams is shown in Table 4 . The moment carrying capacity is determined by the product of the applied force and a distance. The increase in ultimate moment carrying capacity was found to be about $28 \%$ to $36 \%$ and $20 \%$ to $28 \%$ for RHS beams filled with normal mix concrete and fly ash concrete respectively. It can be seen that the void filling increases the moment carrying capacity of RHS Beams. The difference in percentage of increase is due to different compressive strength of the filler material shows in Figure 3.

The Moment-Strain hysteretic graphs for RHS and Concrete filled sections shown in Figure 5 indicate that a uniform mechanism without cracking was observed. The maximum moment reached in each cycle is plotted. The compressive and tensile strain values are within the limit of 0.002 to 0.003 .

The detailed incremental Load-Displacement (deflection) curves (hysteretic loop) are plotted against the number of cycles in Figure 6. This clearly shows that Concrete filling increases the load capacity and flexural behaviour of RHS beams to resist cyclic load especially when the displacement becomes excessive.

Table 4. Comparison of Experimental moment \& Plastic moment

\begin{tabular}{ccccc}
\hline Sl.No & Specimen Label & $\mathbf{M}_{\text {exp }}$ & $\mathbf{M}_{\text {Plas }}$ & $\mathbf{M}_{\text {exp }} / \mathbf{M}_{\text {Pla }}$ \\
\hline 1 & RHS-1 & 9.90 & 10.33 & 0.96 \\
2 & RHS-2 & 10.73 & 10.33 & 1.04 \\
3 & RHS-3 & 10.40 & 10.33 & 1.01 \\
4 & NMC-1 & 13.20 & 10.33 & 1.28 \\
5 & NMC-2 & 14.00 & 10.33 & 1.36 \\
6 & NMC-3 & 13.20 & 10.33 & 1.28 \\
7 & FAC-1 & 13.15 & 10.33 & 1.27 \\
8 & FAC-2 & 12.40 & 10.33 & 1.20 \\
9 & FAC-1 & 13.20 & 10.33 & 1.28 \\
\hline
\end{tabular}

The comparison of experimental ultimate moment capacity $\left(\mathrm{M}_{\text {uexp }}\right)$ with CIDECT standard moment $\mathrm{Mu}(\mathrm{CIDECT})$ is shown in Table 5. The difference of variation is very least.

Table 5. Comparison of Moment Carrying Capacity between Experimental result and CIDECT Standard

\begin{tabular}{ccccc}
\hline Sl.No & Specimen Label & $\begin{array}{c}\mathbf{M}_{\text {uexp }} \\
(\mathbf{k N ~ m})\end{array}$ & $\begin{array}{c}\mathbf{M u}_{\text {CIDECT }} \\
(\mathbf{k N ~ m )}\end{array}$ & $\begin{array}{c}\mathbf{M}_{\text {CIDECT }} / \\
\mathbf{M}_{\text {uexp }}\end{array}$ \\
\hline 1 & NMC-1 & 13.20 & 13.16 & 0.99 \\
2 & NMC-2 & 13.70 & 13.65 & 0.99 \\
3 & NMC-3 & 13.20 & 13.16 & 0.99 \\
4 & FAC-1 & 13.20 & 13.16 & 0.99 \\
5 & FAC-2 & 13.40 & 12.36 & 0.92 \\
6 & FAC-3 & 13.20 & 13.16 & 0.99 \\
\hline Mean & 0.98 & & & \\
\hline
\end{tabular}

\subsection{Ductility}

The graph shown in Figure 6 Load-Deflection curve, at $80 \%$ of ultimate load ductility factor was found. The ductility factor as shown in Table 7 it can be seen that the higher the concrete compression strength, the larger the ductility ratio especially for thinner sections.
To prevent the premature buckling failure of steel hollow specimens, the allowable ratio $(\mathrm{D} / \mathrm{t})$ of the steel hollow sections specified in EC4 as shown below was referenced by Zhao et al (1999)

$D / t \leq \sqrt{\frac{235}{f_{s} y}}$

Where $f_{s} y=$ Steel yield stress in $\mathrm{N} / \mathrm{mm}^{2}$

$\mathrm{D}=$ Depth of the section

$\mathrm{t}=$ Thickness of the section

The ratio of depth to thickness $(\mathrm{d} / \mathrm{t})$ is 29.25 for the sections listed in Table 2 this is less than the corresponding limit of (D/t) 42 (Equation 1). From this investigation demonstrated, that increases in ductility.

A void-filled specimen was bent to a maximum angle $(\Theta)$ of $29^{\circ}$. The rotation angles when the ultimate moment is reached for Concrete-filled RHS beams are shown in Table 6. $\Theta_{\mathrm{NMC}}$ and $\Theta_{\mathrm{FAC}}$ for the sections filled with normal mix concrete and fly ash concrete together with the corresponding value of $\Theta_{y}$ for RHS beam. The increase in rotation angle at the ultimate moment of the concrete filled section is nearly $350 \%$ as shown in Figure 4 . From the above it can be concluded that Concrete filling significantly increases the ductility of RHS beams.

Table 6. Rotation angles at ultimate moment

\begin{tabular}{ccccccc}
\hline Size & $\boldsymbol{\Theta y}$ & $\boldsymbol{\Theta}_{\mathrm{NMC}}$ & $\boldsymbol{\Theta}_{\mathrm{FAC}}$ & $\boldsymbol{\Theta}_{\mathrm{Pla}}$ & $\begin{array}{c}\boldsymbol{\Theta}_{\mathrm{NMC}} \\
\boldsymbol{\Theta}_{\mathbf{y}}\end{array}$ & $\begin{array}{c}\boldsymbol{\Theta}_{\mathrm{FAC}} \\
\boldsymbol{\Theta}_{\mathbf{y}}\end{array}$ \\
\hline $100 \times 50 \times 3.2$ & $8^{\circ}$ & $29^{\circ}$ & $25^{\circ}$ & $21^{\circ}$ & $3.62^{\circ}$ & $3.45^{\circ}$ \\
\hline
\end{tabular}

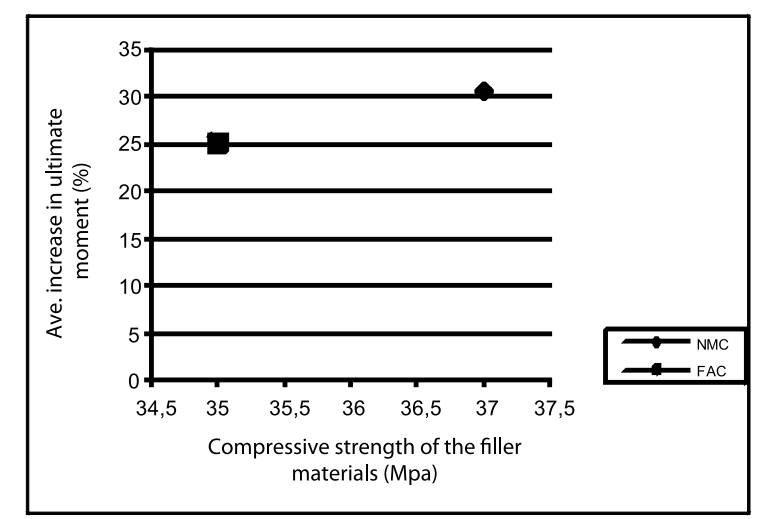

Fig. 3. Average increase in ultimate moment capacity

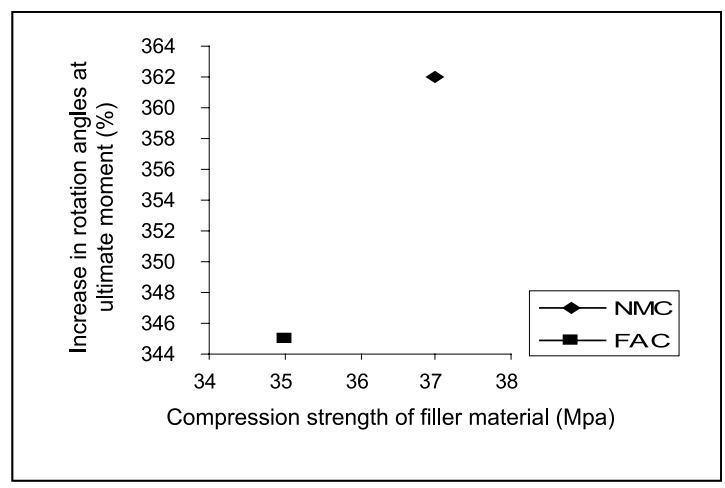

Fig. 4. Increase in rotation angles at ultimate moment 


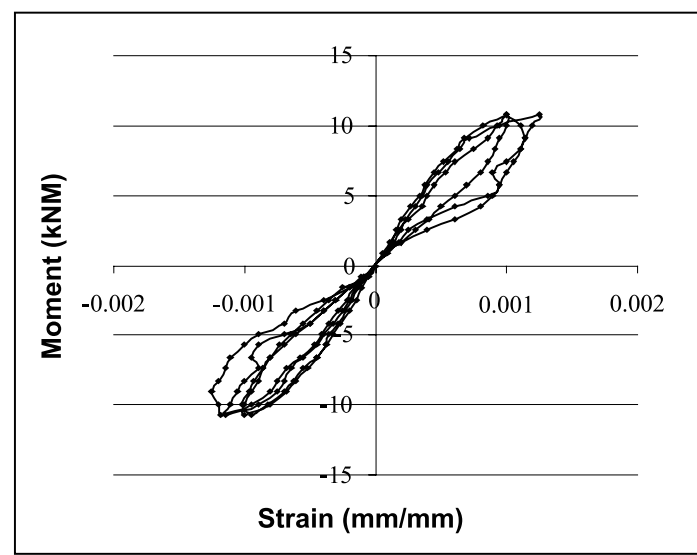

Fig.5 (a) Rectangular Normal Mix Concrete

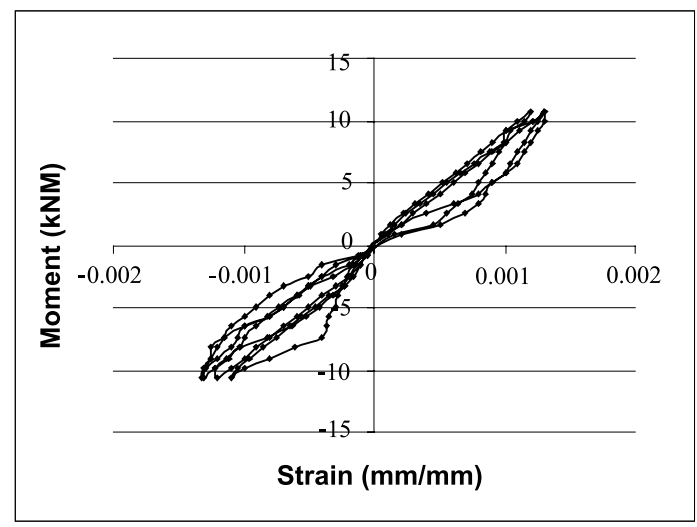

Fig.5 (b) Rectangular Fly Ash Concrete

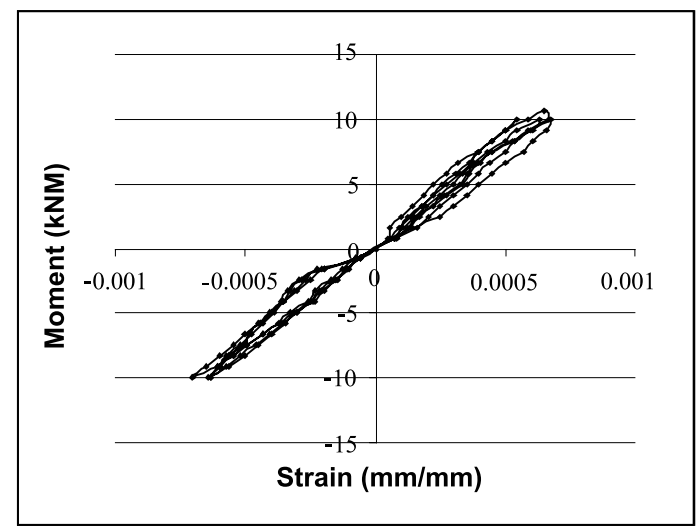

Fig.5 (c) Rectangular Hollow Section

Fig.5 Moment-Strain hysteretic loop curves

\subsection{Energy absorption capacity and Stiffness degradation}

The energy absorption capacity of the beam members can be approximated as the area enclosed by the hysterecis loop (load-deflection curve) in each cycle shown in Table 7. The energy absorption capacity is increase in rectangular section filled with normal concrete and fly ash concrete is 1.53 times and 1.49 times when compared to hollow section. It can be seen that concrete filling increase the energy absorption.

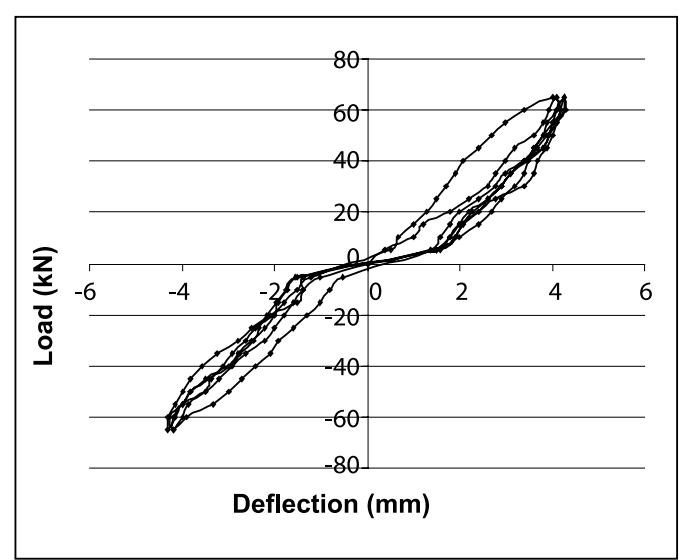

Fig.6 (a) Rectangular Normal Mix Concrete

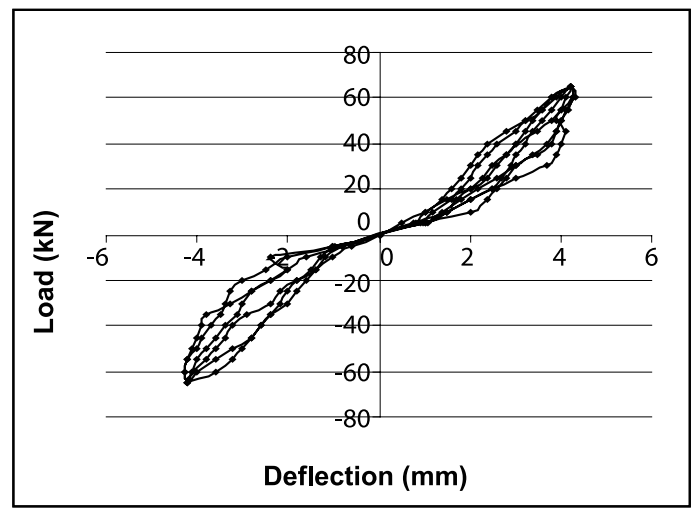

Fig.6 (b) Rectangular Fly ash Concrete

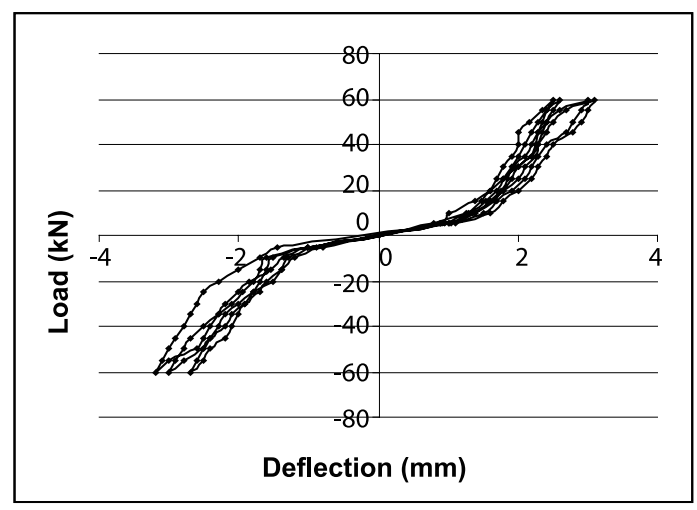

Fig.6 (c) Rectangular Hollow Section

Fig.6 Load -Deflection hysteretic loop curve

The stiffness degradation parameter is calculated by slope of the tangent to the hysteretic loop curve for each cycle is upto $64 \%$ for rectangular hollow section, when the beam specimen filled with normal mix concrete and fly ash concrete its stiffness degradation is $37 \%$ and $36 \%$. From the research it can be under stand that higher compressive strength concrete gives a higher ductility ratio. The ductility factor is improved in concrete filled section when compared to steel hollow section. 
Table 7. Stiffness, Energy absorption \& Ductility factor

\begin{tabular}{ccccc}
\hline Sl.No & Specimen & Stiffness & $\begin{array}{c}\text { Energy } \\
\text { Dissipation }\end{array}$ & $\begin{array}{c}\text { Ductility } \\
\text { factor }\end{array}$ \\
\cline { 3 - 4 } & & $\mathrm{kN} / \mathrm{mm}$ & $\mathrm{kN}-\mathrm{mm}$ & \\
\hline 1 & RHS-1 & 62 & 80 & 2.64 \\
2 & RHS-2 & 66 & 90 & 2.55 \\
3 & RHS-3 & 65 & 100 & 2.6 \\
4 & NMC-1 & 21 & 135 & 4.17 \\
5 & NMC-2 & 26 & 130 & 4.1 \\
6 & NMC-3 & 24 & 150 & 4.15 \\
7 & FAC-1 & 21 & 140 & 3.53 \\
8 & FAC-2 & 26 & 130 & 3.5 \\
9 & FAC-3 & 23 & 125 & 3.45 \\
\hline
\end{tabular}

\subsection{Failure mode}

In RHS sections single outward folding mechanism without crack formed after two cycles. There were no folding mechanisms formed in filled specimen after five cycles. Only Top distortion (in-ward Bend) formed at the top flange portion under cyclic loading shown in Figure 7 in both normal mix concrete and fly ash concrete. The type of mechanism depends on the compactness of RHS section and properties of the filler materials.

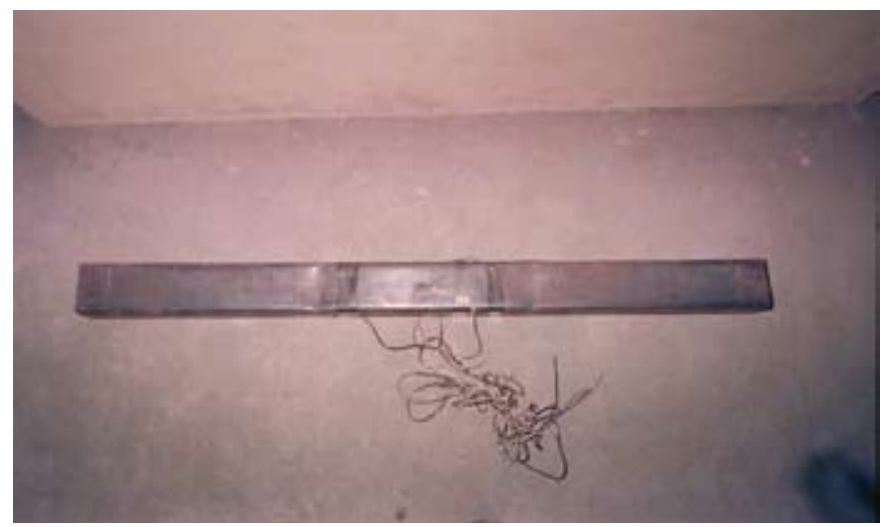

Fig.7 Failure mode shape

\section{Conclusion}

Tests were conducted in three RHS sections (100 x $50 \times 3.2 \mathrm{~mm})$ and six concrete filled sections with two different types of filler materials. The two filler materials used were normal mix concrete and fly ash concrete. The filler materials have different compressive strengths and densities. From the above test the following interesting conclusions are made

1) The increase in ultimate moment capacity mainly depends on the filler material strength.

2) The ultimate moment capacity for concrete-filled RHS members based to the CIDECT standard was found to be good agreement with the experimental ultimate moment capacity of RHS beams filled with normal concrete and fly ash concrete.

3) Two failure modes were observed in the current research programme, namely a single outward folding mechanism without cracks (hollow sections) and no folding mechanism was formed only top distortion (filled sections). The type of mechanism depends on the properties of the filler material.

4) Experimental results show that void filling increases energy absorption capacity, reduces the stiffness degradation and increases the ductility factor.

5) From this research it was observed that fly ash concrete could be used as infill material for an acceptable mechanism.

\section{Acknowledgement}

The authors thanks to the Principal, Head of the department and all the teaching and non-teaching staff members of the department of Civil Engineering, Salem-636 011,TN, India for their full cooperation to complete the research work.

\section{References}

1. Elchalakani, M., Zhao, XL. and Grzebieta, R. H.(2003), "Tests of Circular Tubular Braces Under Cyclic Axial Loading”, Journal of Structural Engineering, vol 129, No 4, pp. 507-514.

2. Zhao, XL. et al.(2002), "Void-Filled Rectangular Hollow Section Braces Subjected to Large Deformation Cyclic Axial Loading”, Journal of Structural Engineering,vol 128, No 6, pp. 746-753.

3. Zhao, XL. and Grzebieta, R. H.(1999), "Void-Filled SHS Beams Subjected to Large Deformation Cyclic Bending", Journal of Structural Engineering, vol 128, No 9, pp. 1020-1027.

4. Hunaiti, Y. M. (1997), "Strength of Composite Sections with Foamed and Lightweight Aggregate Concrete", Journal of Materials in Civil Engineering (ASCE), Vol. 9, No. 2, pp 58-61.

5. Kilpatrick, A. E. and Rangan, B. V.(1995), "The influence of bond upon the load-deformation response of high-strength composite columns", Proceedings of the $14^{\text {th }}$ Australian Conference on the Mechanics of Structures and Materials, Hobart, pp 368-372.
6. Lu, Y. Q. and Kennedy. D. J. L.(1994), "The flexural behaviour of concrete-filled hollow structural sections”, Canadian Journal of Civil Engg., Vol. 21, No 1, pp 111-130.

7. Furlong, R.W.(1968), "Strength of steel encased concrete beam-columns", Journal of Structural Engineering Division, ASCE, Vol. 94, No. ST1, pp 267-281.

8. Assi, I. M., Qudeimat, E. M. and Huniti, Y. M. (2003), "Ultimate Moment Capacity of Foamed and Flyash Aggregate Concrete-Filled Steel Tubes", Steel and Composite Structures, Vol. 3, No. 3, pp 199-212.

9. Angeline Prabhavathy R. and Samuel Knight, G. M. (2006), "Behaviour of Cold-Formed Steel Concrete Infilled RH Connections and Frames", Steel and Composite Structures, Vol. 6, No. 1, pp 71-85.

10. I.S: 4923, "Indian Standard Hollow Steel Sections for Structural Use Specification", Bureau of Indian Standards, New Delhi, Second revision 1997. 


\section{Notations}

Mexp

Mpla

MCIDECT

$\mathrm{t}$

Өy

IONMC, $\mathrm{OFAC}$, $\Theta \mathrm{Pla}$
: Cross-sectional area of concrete

: Cross-sectional area of steel

: External breath of the section

: External depth of the section

: Characteristic strength of concrete

: Characteristic 28-day cube strength of concrete

: Yield strength of structural steel

: Experimental failure moment

: Plastic moment of bare steel section

: CIDECT ultimate moment

: Thickness of steel section

: Rotation angle at yield strength

: Rotation angle at ultimate strength stage 